\title{
A Dozen Images Made in or Near Youngstown, Ohio, That Show Why People Need Both Jobs and Fish
}

\author{
Alice Whittenburg
}

\begin{abstract}
Economy vs. ecology. That's one way to frame the debate that once raged in Youngstown, Ohio, between those who focused on the health of the Mahoning River and those who gave priority to the health of the local economy and the jobs it provided. The latter point of view was often stated in terms of 'Jobs, not fish!' and its proponents asked: Compared to jobs in steel mills, which make it possible for workers to have homes and a decent way of life, what does it matter that fish can't live in the river? Initially, the steel industry benefitted a surprisingly small number of people, mostly owners and investors who treated workers as a resource to be exploited, much like the air and water. But later, thanks to union struggles, workers lived well in the Mahoning Valley, and environmental problems, such as a dirty river, were viewed as a necessary evil. In fact, the foulness of the river assured residents that the mills were going strong and were a source of prosperity. In Youngstown today, deindustrialization has made economic insecurity a fact of life, and the Mahoning, once known as the dirtiest river in the United States, is home to many species of fish. The story of the changes that have taken place in the river landscape centers around the supposed incompatibility of having both jobs along the river's banks and fish in its waters. Ideas from cultural geography can teach us how to view a landscape where so much conflict has played out.
\end{abstract}

When geographer James S. Duncan presented the idea of a landscape as texts which communicate and transmit information, he also argued that reading the landscape can reveal how power relations have played out in a given region. ${ }^{1}$ Sherry Lee Linkon and John Russo built on similar notions in Steeltown USA: Work and Memory in Youngstown as they showed how people's memories, experiences, and struggles are represented in the landscape. Linkon \& Russo also noted that conflict and landscape have a reciprocal relationship. 'Landscapes not only are constructed by economic and social conflict,' they stated, 'but also reinforce such divisions of power.' ( Linkon \& Russo, 2002, pp. 15-16). Such a reading of the Mahoning River landscape yields a complex story about the ways people transformed the natural world in order to benefit from it and then lived with the environmental consequences of that transformation. Though this story is very much about how power and class relations have played out there, in the twentieth century such conflict was often overshadowed by tensions between advocates for steel workers and advocates for the river. Recently, however, the growing understanding of the concept of environmental justice, which has been applied to working-class issues by, among others, Christina Robertson \& Jennifer Westerman

\footnotetext{
${ }^{1}$ More at Medlicott, Carol Ann. (2014) Cultural landscape. Reader's Guide to the Social Sciences, ed. Jonathan Michie. United Kingdom: Taylor \& Francis; specifically, see Duncan, James S. (1990) The City as Text: The Politics of Landscape Interpretation in the Kandyan Kingdom, Cambridge and New York: Cambridge University Press.
} 
in their call for a working-class ecology (Robertson \& Westerman, 2015) and Karen Bell in her agenda for a just transition to sustainability (Bell, 2020), lays the groundwork for alliances between environmentalists and working-class people that were not present when the Mahoning River was an 'industrial stream.' Cultural geographers have also shown us that depictions of a landscape contribute to its meaning(s). ${ }^{2}$ Building on such ideas, Linkon \& Russo examined the landscape of Youngstown through the lens of images and stories, and this essay will view the more specific landscape of the Mahoning River by examining a dozen images created in or near Youngstown since the early twentieth century. Not all of these images depict the river itself, yet all help to clarify the way the conflict between economy and ecology has played out in the Mahoning Valley.

\section{Keywords}

Mahoning River, Youngstown, Ohio, environmental justice, steel industry

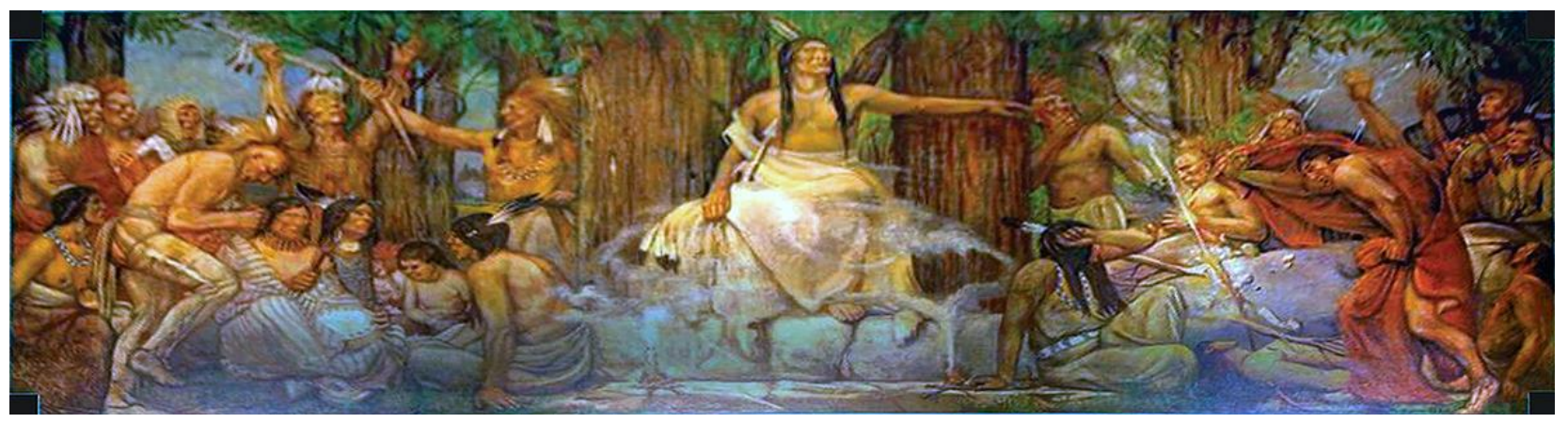

Image 1. Vincent Aderente, Legend of Council Rock, 1910. Photo courtesy of Glenn Liston King, author of Vincent Aderente, American Muralist.

Near the edge of a grassy park on the east side of Youngstown, Ohio, lies a large boulder. This massive rock, legend says, was split by lightning in 1755 while a group of American Indians celebrated a victory in the French and Indian War. The boulder has a name - Council Rock - and it also has an off-center cleft running through it, though most of the rock is still intact. ${ }^{3}$

In 1910 Vincent Aderente painted the 'Legend of Council Rock' mural, which still hangs inside the Mahoning County courtroom in downtown Youngstown. ${ }^{4}$ The mural is also known as 'Indians Celebrating the Victory Over Braddock,' and it portrays a group of Native American men, women, and children sitting and standing around a large boulder from which one of the men seems to be giving a blessing. The painting depicts twenty people, but they must constitute only a small part of the group because, at least according to the legend, hundreds were killed when a lightning bolt

\footnotetext{
${ }^{2}$ Again, see Medlicott; specifically, see Daniels, Stephen and Cosgrove, Denis. Introduction: iconography and landscape. (1988) The Iconography of Landscape: Essays on the symbolic representation, design and use of past environments. Stephen Daniels and Denis Cosgrove, eds. Cambridge: Cambridge University Press.

${ }^{3}$ Heineman, Ted. (n.d.). The Legend of Council Rock. Riverside Cemetery Journal. http://riversidecemeteryjournal.com/Places/Places/page9.html

${ }^{4}$ Ricciutti, Gerry. (May 1, 2019). Work underway to restore 110 -year-old mural in Mahoning County courtroom. WKBN First News 27 website. https://www.wkbn.com/news/local-news/work-underway-to-restore-110-year-oldmural-in-mahoning-county-courtroom/
} 
later struck the rock. That the legend of Council Rock centers around a large human toll during a victory celebration might seem like schadenfreude on the part of the legend's creators - implying that these Native people paid with their lives for defeating Braddock - but the painting itself depicts not their terror and destruction but the calm that came beforehand.

What came much earlier beforehand was the presence of Native Americans in the Mahoning Valley - thousands of years before European settlers came. ${ }^{5}$ At the time Europeans arrived, Iroquois and Delaware peoples, among others, were fishing in or hunting near the river, using it for transportation, and living in small settlements nearby. The name Mahoning is said to be of Lenape (Delaware) origin, and Native uses of the river were compatible with the well-being of a riparian habitat. ${ }^{6}$ By the early nineteenth century, however, most Native Americans had been forced out of the eastern United States, and then the Mahoning River began to serve the needs of industry. ${ }^{7}$ That's when it became emblematic of a conflict between economy and ecology.

In the introduction to a book of photos called Youngstown, Ohio, published in 1912, author A.B. Christy claimed that the city was 'regarded second only to Pittsburg [sic] among the leading iron and steel centers of the world...' Reasons cited for why this was so included the city's location near 'inexhaustible mines of the ore regions,' 'endless coal fields of Pennsylvania,' and the fact that it was 'watered by an inexhaustible stream from which the valley derives its name. ${ }^{, 8}$ It is notable that the Mahoning River was referred to as a stream, but more so that the word inexhaustible appeared twice in one short page of text.

A belief that the land, air, and water were inexhaustible resources there for the taking was consistent with the brutal process of wresting the so-called New World from its original inhabitants. And attitudes toward the Mahoning River during the twentieth century clearly showed a connection between these two mindsets. In 1965, testifying before a Department of Health, Education and Welfare (HEW) commission on the pollution of the river, Congressman Michael Kirwan said that the Mahoning, '... is now and always has been and, I trust, always will be, an industrial stream.' He dismissed the absence of fish as largely a concern of 'our sporting population,' and concluded by saying that while Native Americans might once have fished in a pristine Mahoning River, '[t]he Indians had no television to watch and no jet planes on which to ride. And I ask you now, who was better off, the Indians or you and I, here, today? If losing the fish in the industrialized stretch of the Mahoning was the penalty we had to pay, then I say, and I think you will agree, it was a penalty worth paying."9

\footnotetext{
${ }^{5}$ American Indians and Early America. Ohio History Central. https://ohiohistorycentral.org/w/American_Indians\#American_Indians_and_Early_America ${ }^{6}$ Gannett, Henry. (1905). The origin of certain place names in the United States. Washington: Government Printing Office. Via Internet Archive. https://archive.org/details/bub_gb_9V1IAAAAMAAJ/page/n195/mode/2up

${ }^{7}$ Saunt, Claudio. (23 April 2020). Indian removal. aeon. https://aeon.co/essays/the-worlds-first-mass-deportationtook-place-on-american-soil

${ }^{8}$ Christy, A.B. (1912) Youngstown, Ohio. Portland, Me., L.H. Nelson Co. Via Internet Archive. https://archive.org/details/youngstownohio00chri/page/n5

${ }^{9}$ Groves, E.R. (February 24, 1965) Local Folks Were a Little Indignant Over Federal Hearing on Mahoning River Pollution. Farm and Dairy. [Source: Clippings file on Mahoning River at the main branch of the Public Library of Youngstown \& Mahoning County]
} 
The idea that people must choose between the health of the land and their own economic wellbeing was a common theme in Youngstown during the twentieth century, and though such debate rings hollow now that the mills have mostly closed down and the health of the river has improved, the consequences of viewing a river as an 'inexhaustible stream' or an 'industrial stream' are still worth examining - along with the notion that, in the nineteenth and early twentieth centuries at least, human beings in the Mahoning Valley were also regarded as inexhaustible, industrial resources.

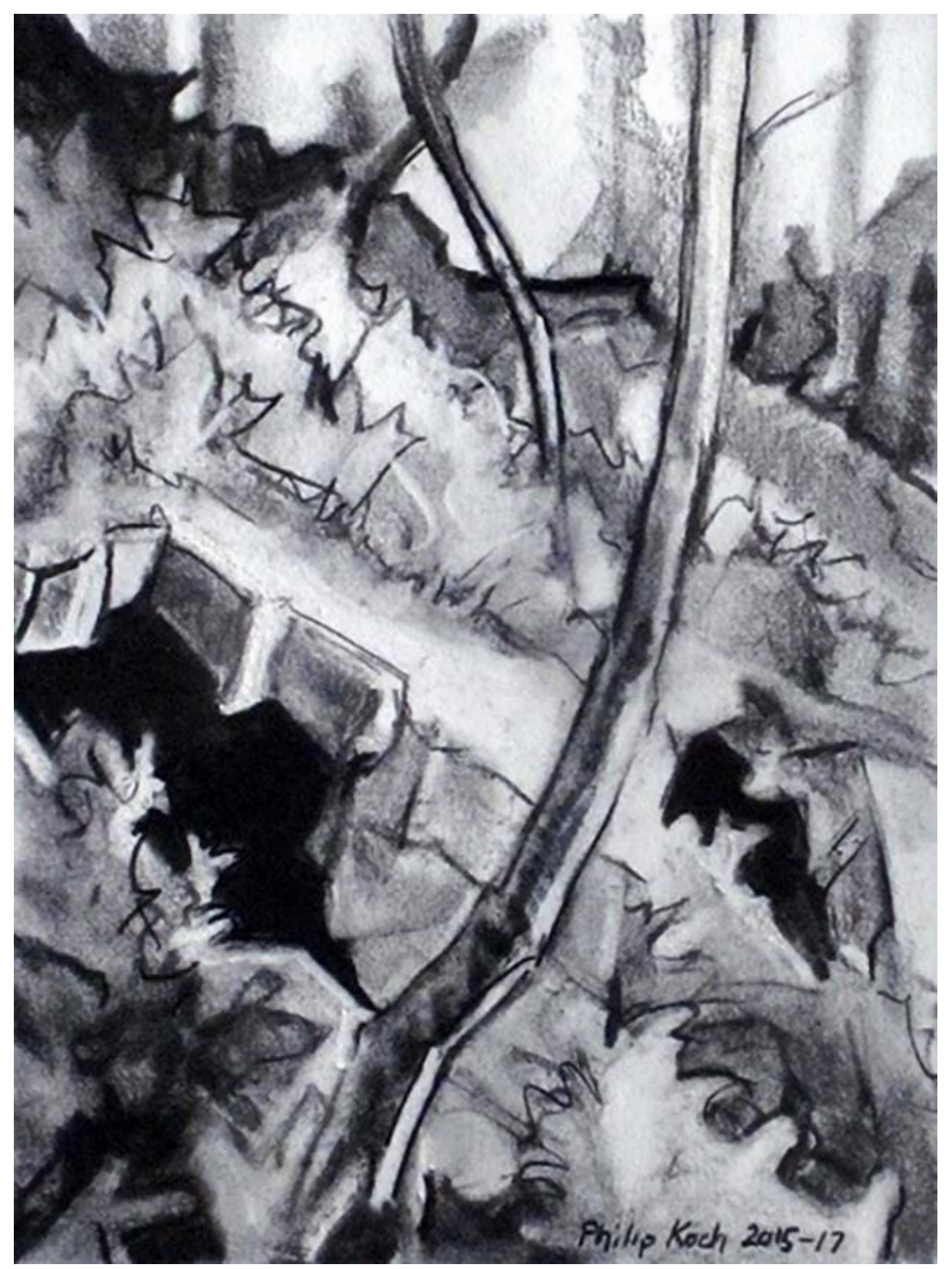

Image 2. Philip Koch, 'Coke Ovens, Leetonia, Ohio,' vine charcoal drawing, 2015-2017, from the collection of Allen Memorial Art Museum in Oberlin, $\mathrm{OH}$; used by permission of the artist.

In this drawing by landscape painter Philip Koch, the curve of a vegetation-covered hillside is mirrored by the shapes of saplings reaching toward the sun. The two irregular dark openings that 
dominate the lower half of the drawing, however, lend an ominous tone to the otherwise tranquil scene. These ragged holes represent the entrances to in-ground coke ovens which were once used to transform local low-grade coal into the coke needed to make iron and steel. Two hundred such ovens, built in Leetonia about twenty-five miles from the Mahoning in 1866, burned 24-hours a day in what must have seemed like a small but intense corner of hell. Though the ovens ceased operating during the Great Depression, they remain as a monument to one of the region's earliest conflicts between economy and ecology. ${ }^{10}$

When he made his first version of this drawing, Koch was Artist in Residence at the Burchfield Penney Art Center, which gave him a chance to work on location in some of the same landscapes Charles Burchfield had painted a century earlier. ${ }^{11}$ Though Burchfield tended toward a kind of landscape painting that depicted vegetation, hills, sky, and living creatures with an almost fantastical intensity, his early work had also focused on the consequences of industrialization for people and the natural world.

In 2015 Koch followed Burchfield's lead to Leetonia where the 1918 painting 'Abandoned Coke Ovens' had gotten its inspiration; the painting shows the gaping holes left by burning ovens and the resultant trauma for people whose homes face the blasted, blighted scene. This was just one example of mining and industrial operations that had reduced land around Burchfield's nearby hometown of Salem to a 'raw, shattered landscape.' ${ }^{12}$ Koch considers Burchfield's work to be an example of early and genuine environmental consciousness, and he says, 'Each generation needs a new image of what our earth looks like in our time. There will always be a need for landscape painters to show us where we live. ${ }^{13}$

In 1844, shortly before the Leetonia coke ovens were built, coal also helped to shape the future of the Mahoning River landscape. The discovery of a particularly dense, dark coal that didn't require a separate coking process made the expansion of the local iron- and steel-making industries possible. A few decades later, more than twenty blast furnaces had been built, mostly along the Mahoning River from which water could be drawn for industrial processes. ( Linkon \& Russo, 2002, p. 19) Conflict between mine-owners and workers, especially over low wages, led to several strikes at local mines; but by the early twentieth century, Youngstown had ceased to be a 'community of small-scale industries, farms, and shops' and had become a city of steel mills. ( Linkon \& Russo, 2002, pp. 21-24) The population grew as people came to find jobs in the mills, and the river took on its role as a servant of industry.

\footnotetext{
${ }^{10}$ Nelson, Elisabeth R. (n.d.) Leetonia Beehive Coke Ovens. Atlas Obscura. https://www.atlasobscura.com/places/leetonia-beehive-coke-ovens

${ }^{11}$ Koch, Philip (May 10, 2016). Blistering Vision: Burchfield's Coke Ovens. Burchfield Penney Art Center website. https://www.burchfieldpenney.org/general/blog/article:05-10-2016-12-00am-blistering-vision-burchfield-s-cokeovens/

${ }^{12}$ Weekly, Nancy. (n.d.) Deserted Miner's Home. Burchfield Penney Art Center website. https://www.burchfieldpenney.org/exhibitions/exhibition:12-12-2014-02-22-2015-deserted-miner-s-home/

${ }_{13}$ Burchfield Penney Art Center (n.d.) Time Travel in the Burchfield Archives: Philip Koch. Burchfield Penney Art Center website. https://www.burchfieldpenney.org/exhibitions/exhibition:04-13-2018-07-29-2018-time-travel-inthe-burchfield-archives-paintings-by-philip-koch/
} 


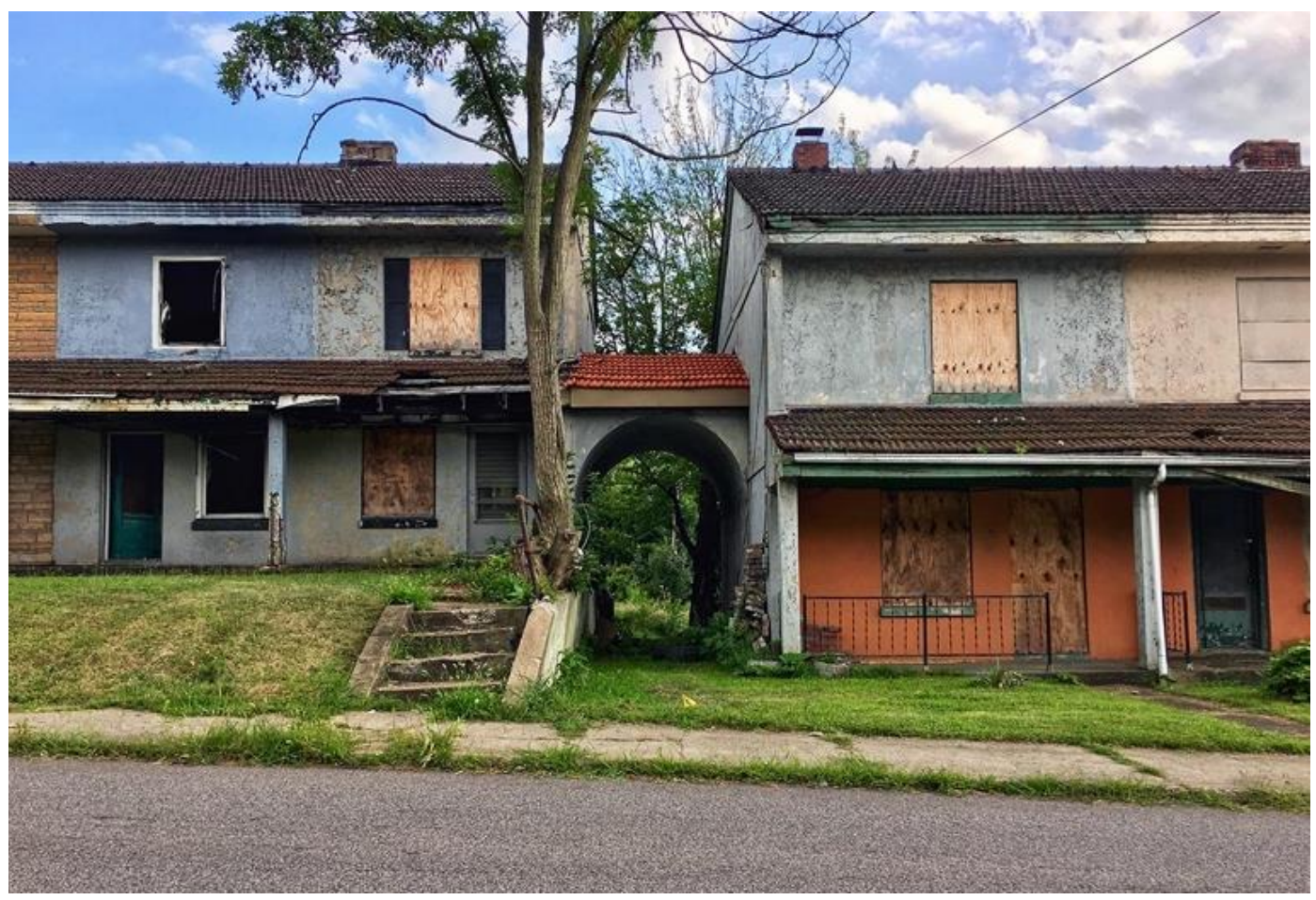

Image 3. Photo of Youngstown Sheet \& Tube Company Housing by Kaeleigh Herstad, 2018; used by permission.

This 2018 photo by Kaeleigh Herstad, taken for her own blog, ${ }^{14}$ is much like one that appeared in a 1930 ad from Sheet \& Tube's Buckeye Land Company. ${ }^{15}$ The ad described rental units in Campbell which offered hot and cold running water, sewer lines, electricity, and were 'easy walking distance' to the north gate of the Campbell Works, though of course the windows had shutters then instead of plywood coverings and the roofs were watertight. In 1917 and 1918, these homes were built by Youngstown Sheet \& Tube for their employees because having a decent place to live was something workers valued highly and meeting their needs also contributed to the company's stable operations.

In the early 1900s, back when the city of Campbell was still called East Youngstown, most of the homes for mill workers there lacked sewer lines and indoor plumbing. According to one account, there was also garbage in the streets and a 'clinging, all-pervasive mud.' ${ }^{16}$ Many of the workers were immigrants from eastern and central Europe, and it was partly their living conditions, along with their anger over low wages, that motivated them to go on strike in 1916.

\footnotetext{
${ }^{14}$ Herstad, Kaeleigh. (October 8, 2018). 'The Workingmen's Colony': Labor Conflict and Historic Preservation in Campbell, Ohio. Kaeleigh Herstad's blog. https://kaeleighherstad.com/2018/10/08/the-workingmens-colony-laborconflict-and-historic-preservation-in-campbell-ohio/

${ }^{15}$ Joo, Johnny. (June 18, 2018). Youngstown Sheet \& Tube: The First Concrete Pre-Fab Estate in the World. Architectural Afterlife. https://architecturalafterlife.com/2018/06/youngstown-sheet-tube-the-first-concrete-pre-fabestate-in-the-world/

${ }^{16}$ Fitch, John A. (January 22, 1916). Arson and Citizenship. The Survey. East Stroudsburg, Pa., etc., Survey Associates. https://archive.org/details/surveycharityorg35survrich/page/478/mode/2up?q=East+Youngstown
} 
It was a violent strike, resulting in eight deaths and twelve injuries, and it was a destructive strike, in which much of East Youngstown was burned to the ground. A grand jury indicted Sheet \& Tube for mistreatment of its workers, though a state judge later overturned that indictment. But in response to the disruption created by the strike, Sheet \& Tube built four plats of workers' housing. The homes in East Youngstown that were located downwind from the Campbell works were designated as a rental area for recent immigrants and African-Americans, groups which were, in turn, segregated from each other. (Linkon \& Russo, 2002, pp. 28-29 and p. 35) The 1930 ad, by the way, stated that the homes it pictured were 'for white workers.'

It's notable that the living conditions in East Youngstown helped to bring about the 1916 strike. People lived in East Youngstown because they could walk to the mill, but they couldn't tolerate the poor sanitation and the garbage and the mud, in addition to their low wages and unacceptable working conditions. The foulness of the nearby Mahoning may also have taken a toll because there was human waste as well as industrial effluent in the river by that time. When the Mahoning flooded in 1913, for example, low-lying homes and workplaces were inundated with contaminated river water. ${ }^{17}$

The problem of raw sewage in the Mahoning persisted well into the twentieth century because sewage treatment facilities were expensive to build and cities chose to dump their waste into the river instead. The impetus for change, at least in terms of eliminating human waste from the water, had more to do with the interests of the steel industry than concerns for public health. In 1933, a Youngstown Sheet \& Tube Co. engineer called for water from a nearby lake to be released into the Mahoning because the river water wasn't '...diluted sufficiently, causing bad odors and miasmatic conditions affecting the men in the mills.' ${ }^{18}$ And in 1936 industry spokesmen complained that the solid waste in the river clogged the pumps used for the mills' water intake. ${ }^{19}$ Long after the 1916 strike, the waste products of nearby mills and communities would have made life for workers difficult - and nearly impossible for fish.

\footnotetext{
${ }^{17}$ Mahoning Valley Historical Society. (March 14, 2013). The Flood of 1913. Mahoning Valley Historical Society website. https://mahoninghistory.org/2013/03/14/the-great-flood-of-1913/

${ }^{18}$ The Youngstown Vindicator. (August 18, 1933). Boehme Says Release to River Was Step to Guard Health. The Youngstown Vindicator. [Source: Clippings file on Mahoning River at the main branch of the Public Library of Youngstown \& Mahoning County]

${ }^{19}$ May, Paul. (September 2, 1936). National Board Will Study Mahoning River Sanitation. The Youngstown Vindicator [Source: Clippings file on Mahoning River at the main branch of the Public Library of Youngstown \& Mahoning County]
} 


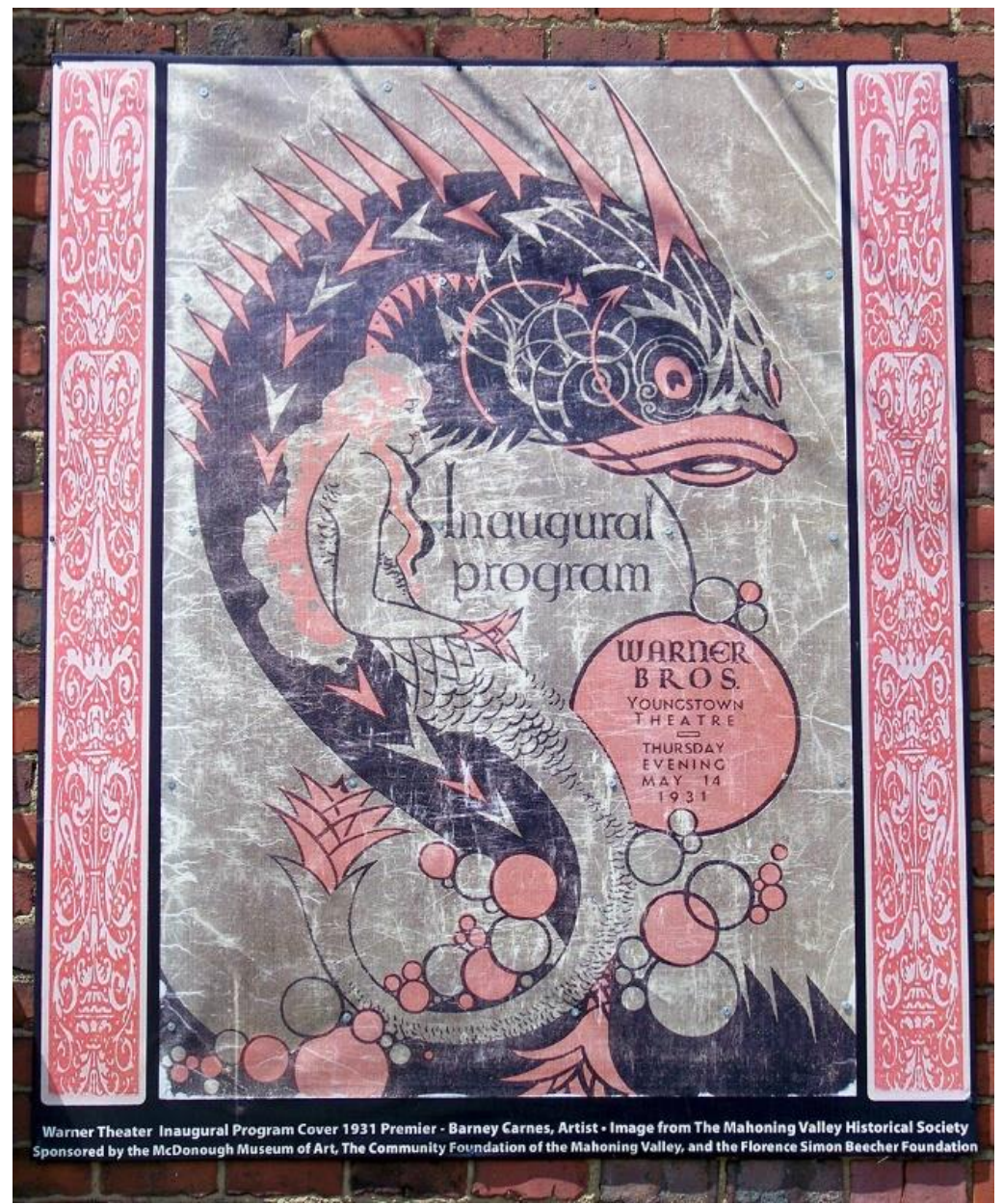

Image 4. Mural of Warner Theatre Inaugural Program Cover 1931 Premier, Barney Carnes, Artist. Photo by the author. Used by permission of the Mahoning Valley Historical Society, Youngstown, Ohio.

On a brick wall near the viaduct over the Mahoning River in Girard, Ohio, there's a mural of a fantastical fish. It has a full-lipped mouth and more than a dozen spines protruding from its arched back. ${ }^{20}$ It looks like a carp from a Japanese wood block print, but it also has a distinct Art Deco quality. Cleaving to the fish's side is a much smaller mermaid with a curved tail. Bubbles rise from below the two creatures and seem about to burst against the arrow-like markings on the fish's body. The largest of these bubbles contains the text: 'Warner Bros. Youngstown Theatre' and a date of May 14, 1931.

The fish and its mermaid companion were designed by graphic artist Barney Carnes to appear on the cover of a program for the 1931 theatre opening in downtown Youngstown. ${ }^{21}$ The Warner brothers, founders of the eponymous film studio, grew up in Youngstown, and the opening was a posh, invitation-only event. The new theatre was just a few blocks from the Mahoning, and some

\footnotetext{
${ }^{20}$ Tribune Chronicle. (October 3, 2016). Murals beautify downtown Girard. Tribune Chronicle. https://www.tribtoday.com/news/local-news/2016/10/murals-beautify-downtown-girard/

${ }^{21}$ Guerrieri, Vince. (February 2017) Screen Legends. OhioMagazine.com. https://www.ohiomagazine.com/ohio$\underline{\text { life/article/screen-legends }}$
} 
well-dressed invitees would likely have crossed the river that night when they came to watch the premier of a film called The Millionaire. It's appropriate that a carp-like fish appeared on that program cover because the carp is a symbol of prosperity, and this event attracted prosperous people to see a film that celebrated good fortune, despite the downturn the economy had recently taken.

The movie, as fantastical as the fish in its own way, opens with scenes of workmen who love their boss, the sterling James Alden, a Henry Ford sort of man whose employees so admire him that the most respectful of them names his son after Alden. This millionaire has been told by his doctor to retire and has been encouraged to do so by his wife, but he loves his work, he wants to work; he looks out the window at Alden Engineering shimmering in an industrial haze and he hates to leave it. But when he moves to California and, on the sly, succeeds in building up a small gas station business, he begins to recover some of his old vigor; in this way the film implies that productive work is important, even to a millionaire.

The Mahoning River at that time was also recovering some of its old vigor because the Great Depression was in full swing and consequently the steel mills were not. A 1932 article in The Youngstown Vindicator announced that 'They're Fishing in the Mahoning Now That the Mills Are Down' and contained one of the first instances of the widely quoted local dictum that jobs should be more important to the people of the Mahoning Valley than fish. ${ }^{22}$ Because when there are no jobs there are fish, and when there are fish there are no jobs - or at least that's the way it always seemed to be.

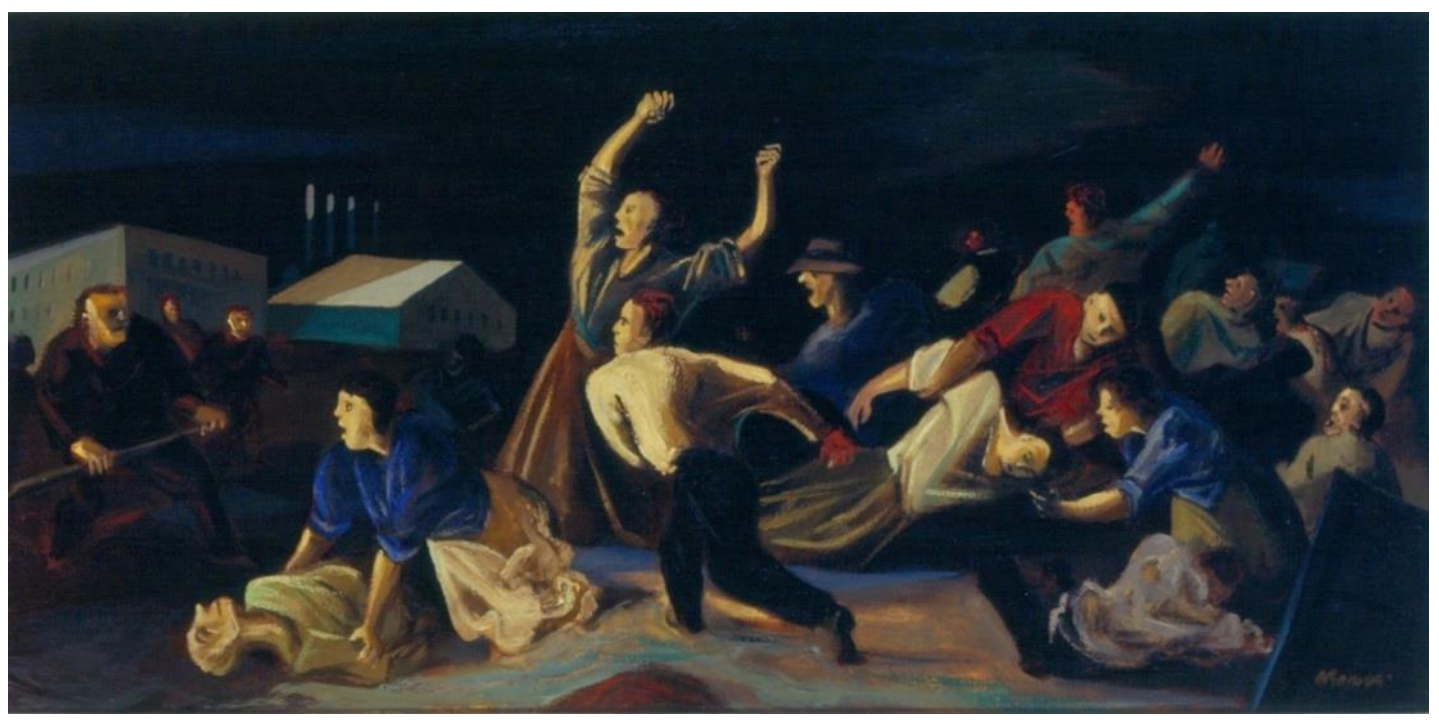

Image 5. William Gropper, Youngstown Strike, 1937. Museum Purchase 1985. Collection, The Butler Institute of American Art, Youngstown, Ohio. Used by permission of Craig Gropper.

In June of 1937, artist William Gropper came to Youngstown to cover the Little Steel Strike, and he was outside Republic Steel at the Stop 5 gate on Poland Avenue when the Women's Day

${ }^{22}$ The Youngstown Vindicator. (June 23, 1932). They're Fishing in the Mahoning Now That the Mills Are Down. The Youngstown Vindicator. [Source: Clippings file on Mahoning River at the main branch of the Public Library of Youngstown \& Mahoning County] 
massacre took place. ${ }^{23}$ Note that the Little Steel Strike didn't get its name because it was a little thing but because the workers were striking for the right to join a union and receive better treatment at the mills owned by companies collectively known as Little Steel. ${ }^{24}$ (U.S. Steel was Big Steel and had already been unionized.)

Gropper wrote that women had brought their children with them so they could picket in support of their striking husbands. When the police told them to go home where they belonged, the women refused, and they were teargassed. Strikers responded to their cries and joined in the resulting fray. Gropper made a series of drawings - as intense and expressionistic as Käthe Kollwitz prints - to accompany his story. They showed workers reacting to teargas, handkerchiefs to their faces; a woman supporter holding one fist in the air while an anxious child grasps her other arm; police firing into the crowd; a dozen men and women falling and fleeing while armed men lurk menacingly under an archway; and other similar scenes. The Youngstown Strike painting is sometimes said to depict the 1916 strike, but it is similar in emotional tone to Gropper's drawings of the Women's Day massacre. ${ }^{25}$ He reported that two strikers were killed and twenty-eight were injured that day, very near to the Mahoning, just outside Republic Steel.

During the Little Steel Strike, some workers chose to stay in the mills and work. ${ }^{26}$ The company air-lifted food and supplies to them. These workers really did have the same kind of loyalty to their bosses that the fictional Millionaire's employees felt for him, but for many workers choosing to support the strike was a less complicated decision than choosing between having a job and having a healthy river.

The river was being killed then, too, but in a slow-mo sort of way as it passed by the mills and picked up heat and toxins. Life was probably not so bad for the river and the fish during the strike. But the strikers did eventually go back to work and, although it took a few years, they got to join the Steelworkers Union. Then came World War II with a consequent need for lots of steel, and the mills heated up again and the fish began to die again, and for a while there were lots of jobs again.

\footnotetext{
${ }^{23}$ Gropper, William. (July 3, 1937). Gropper Visits Youngstown. The Nation. From A Special Collections Research Center Exhibition at Syracuse University Library. https://library.syr.edu/digital/exhibits/g/Gropper/LargeImage/GropperVisitsYoungstown P14.jpg

${ }^{24}$ Blake, Benjamin. (February 2008). Ohio's Steel Mill War. The Little Steel Strike of 1937: Big Steel and Little Steel. Cleveland History, Issue 3.

https://academic.csuohio.edu/clevelandhistory/Issue3/articles/steelpage2content.htm??

${ }^{25}$ O'Brien, Dan. (August 19, 2019). Framing History Is Butler's Art. The Business Journal. 2021. https://businessjournaldaily.com/framing-history-butlers-art/

${ }^{26}$ Republic Steel Corporation. 1937 Little Steel Strike scrapbook. Youngstown Historical Center of Industry \& Labor. See description. https://ohiomemory.org/digital/collection/p15005coll10/id/4852/
} 


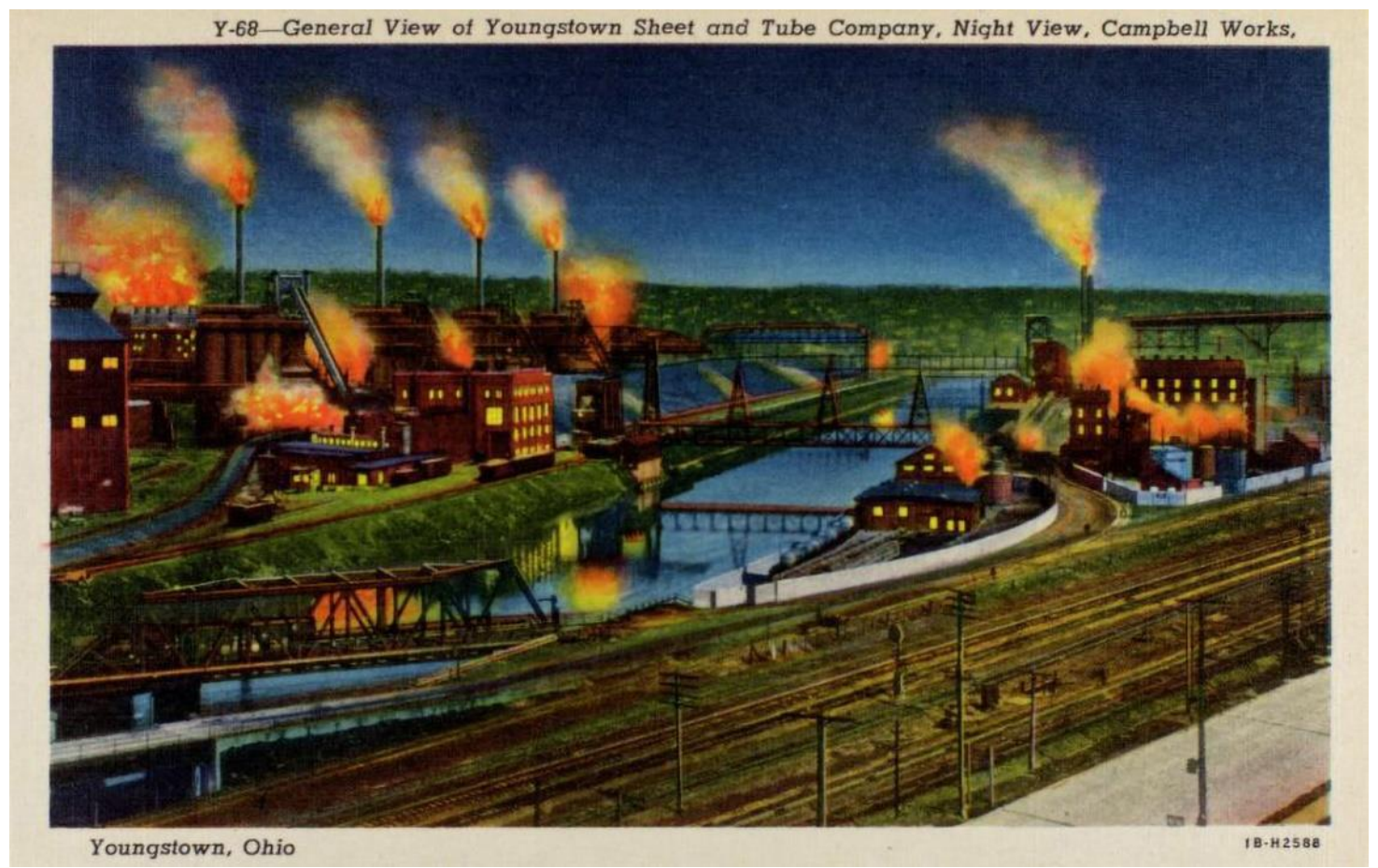

Image 6. General View of Youngstown Sheet \& Tube Company, Night View Campbell Works, 1942, Newberry Library, Curt Teich Postcard Archives; public domain image.

In this night view of the Campbell Works, the mill is a colorful place, maybe even a beautiful one. The mill buildings with bright yellow windows have a cheery, homelike quality, and the tall flares appear almost celebratory, like fireworks or birthday candles. The dark green hills behind the mill seem unscathed by the workings of industry; the tranquil blue river reflects the sky and the glow of a few yellow-orange flames. Only the railroad tracks that skirt the lower edge of the picture and the bridges across the river seem completely utilitarian, a drab latticework of connective tissue. And in this idealized depiction of the industrial process, no workers can be seen.

Flares like the ones in this image were there to burn off coke gas and other flammable byproducts of the steelmaking process, and like the soot and smoke in the air, they were a sign that people had jobs and the mills were going strong. ${ }^{27}$ In 1941 when this postcard by an unknown artist was printed by the Curt Teich Company, the Sheet \& Tube was producing the steel needed for the war effort, and later, Sheet \& Tube products were used to make consumer goods during times of postwar prosperity.

Images like these are examples of what Sherry Lee Linkon and John Russo call promotional materials about the steel industry and Youngstown, and they showed how impressive and significant the process of steelmaking could be. What such images failed to acknowledge,

\footnotetext{
${ }^{27}$ For a more contemporary example, see Vergano, Dan. (April 6, 2019) People Are Getting Sick from a US Steel Factory That Is 'Grossly Violating' Health Standards, Experts Say. BuzzFeed News. https://www.buzzfeednews.com/article/danvergano/us-steel-pollution-asthma-clairton-pennsylvania
} 
however, was how hard the work could be or how divisive race and ethnicity and class could be. ( Linkon \& Russo, 2002, p. 69) Neither, for the most part, was there an acknowledgement of the damage being done to the natural world.

Yet even in an image like this one there appears, in thrall to the hot, dirty business of making steel, a sluggish flow of water, a river, the Mahoning, which was caught up in the process. It was also used up by the process. How could the water support any fish in the midst of all this? The water had to be given over to the needs of steel, and only when there was a strike, from July to November of 1959 , did the river recover a little, did the fish make a small comeback. ${ }^{28}$

Among other operations, there was a coke plant at the Campbell Works. 'Hot, heavy, hazardous' is a phrase that was used to describe certain jobs at the mill, such as those in the coke plant where fumes could be toxic and the heat could be extreme. These jobs often went to African-American workers who were also forced, because of housing discrimination, to live closer to the mills where air quality was poor, as in the company housing in Campbell. ${ }^{29}$ These were among the significant things that weren't acknowledged in any image of a beautiful mill.

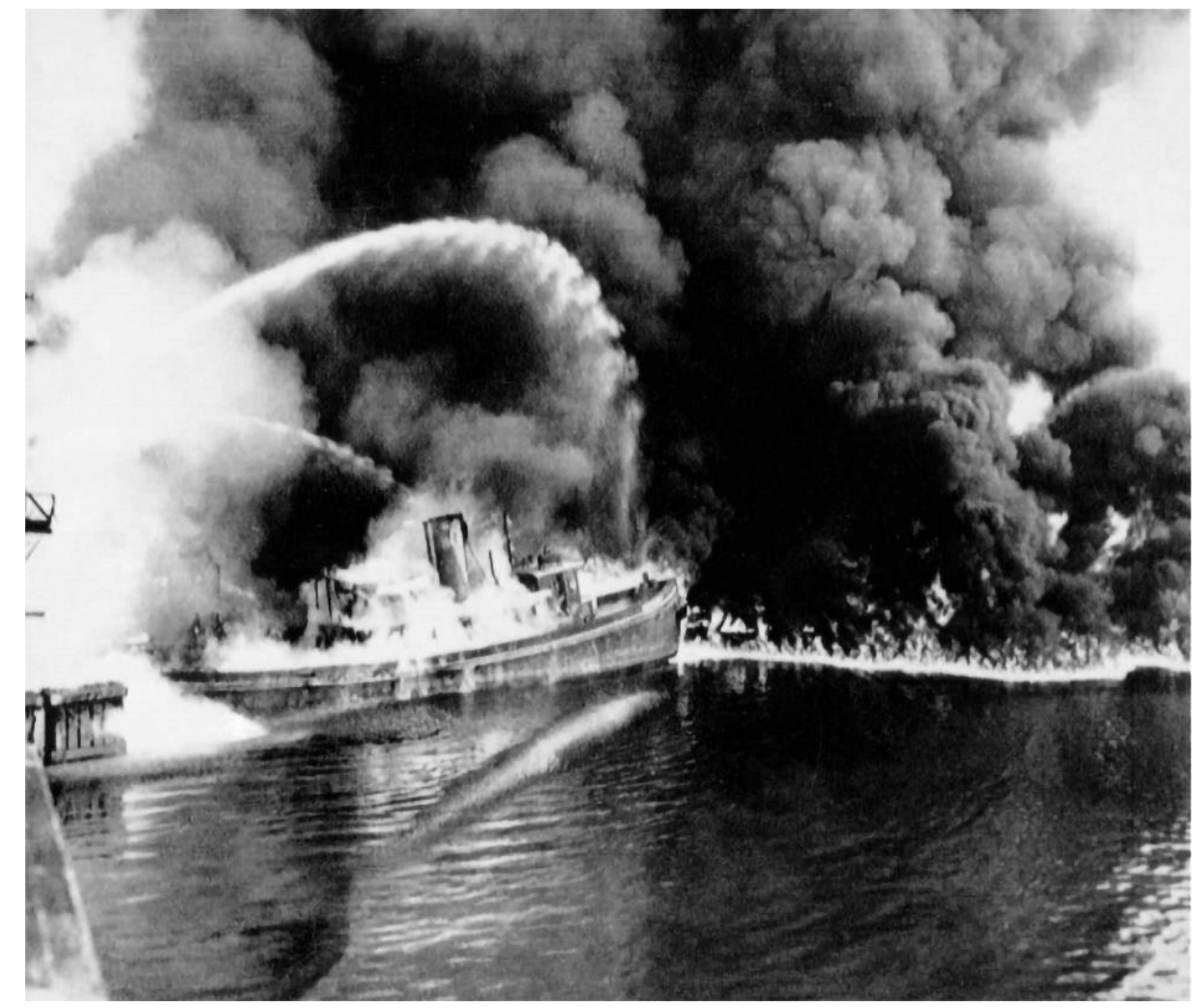

Image 7. A fire tug fights flames on the Cuyahoga River near downtown Cleveland on June 25, 1952. The Plain Dealer. Photo @ 1952 The Plain Dealer. All rights reserved. REPRINTED/USED with permission.

\footnotetext{
${ }^{28}$ Johnson, Linda J. (February 5, 1995, page 11; see sidebar Watching the River Flow). Overflowing Sewage Adds to Problem. The Youngstown Vindicator. [Source: Clippings file on Mahoning River at the main branch of the Public Library of Youngstown \& Mahoning County]

${ }^{29}$ For another view of environmental racism and the steel industry, see Tony Buba's video: How Race, Class, and Pollution Define | Braddock, PA: Part 2. https://www.youtube.com/watch?v=Iaiv8$\underline{\text { PSltw\&list=PLZVnnAt5 5laazgQtL4gc0vMqvMvhp8Hl\&index=3 }}$
} 
The setting of this well-known photo isn't Youngstown, but it could be. A river is on fire. As flames impinge on the oil-slicked water, clouds of black smoke billow into the sky. The crew on a small tugboat works hard to fight the fire. The odd blend of water, flame, and smoke calls to mind a surrealist painting, yet the scene is not fantastical.

This photo of the burning Cuyahoga River appeared in the August 1, 1969, issue of Time. ${ }^{30}$ The issue was widely read because it covered another water-related scandal, the incident at Chappaquiddick. The article described the Cuyahoga as so polluted by industrial waste and sewage that it 'oozes rather than flows,' and said the river couldn't support any living things, 'even leeches and sludge worms that usually thrive on wastes.' The photo shocked readers, and Time's coverage elicited outrage about the state of waterways in the United States.

To be accurate, the photograph of the burning Cuyahoga used by Time shows a fire from June 25, 1952, because there were no photos of the June 26, 1969, fire the article describes. ${ }^{31}$ The Cuyahoga had caught fire many times, and the incident didn't receive much coverage in Cleveland. Industrial rivers like the Mahoning and the Cuyahoga burned because of oil or grease-soaked debris dumped into the water by the mills. ${ }^{32}$ In fact, at that time, the Mahoning and the Cuyahoga weren't really rivers - that is, ecosystems of moving water; instead, they were industrial ancillaries and so they burned as industry did.

The next day Cleveland Mayor Carl Stokes held a press conference at the site of the fire, and he later testified before Congress, calling for laws to clean up Cleveland's waterways. His efforts helped bring about the Clean Water Act and the EPA. ${ }^{33}$

But the Mahoning River didn't benefit much from these new laws and agencies, at least not right away. In the early 70s the Ohio Water Pollution Control Board set 'Fresh water fishery' standards on the Mahoning's industrialized stretch, ${ }^{34}$ but in 1973 Ohio Governor Gilligan was asked by industry to lighten that requirement. ${ }^{35}$ In 1974 the EPA agreed to compromise. ${ }^{36}$ The idea of a fresh-water fishery so near the mills conflicted with the notion that steel was more important than fish.

\footnotetext{
${ }^{30}$ Latson, Jennifer. (June 22, 2015). The Burning River That Sparked a Revolution. Time. https://time.com/3921976/cuyahoga-fire/

${ }^{31}$ Ohio History Central. (n.d.) Cuyahoga River Fire. Ohio History Central site.

https://ohiohistorycentral.org/w/Cuyahoga_River_Fire

${ }^{32}$ Dykstra, Peter. (June 9, 2019). A river burns through it. Environmental Health News.

https://www.ehn.org/cuyahoga-river-50th-anniversary-fire-2638730182.html

${ }^{33}$ DeMarco, Laura. (September 19, 2019). The Burning River: A look back at the twisting history of the Cuyahoga. The Plain Dealer. https://www.cleveland.com/life-and-culture/g661-2019/05/bf83f6d14d5980/the-burning-river-alook-back-at-the-twisting-history-of-the-cuyahoga-vintage-photos.html

${ }^{34}$ The Youngstown Vindicator. (September 30, 1971). Steel, OE Protest River Costs. [Source: Clippings file on Mahoning River at the main branch of the Public Library of Youngstown \& Mahoning County]

${ }^{35}$ The Youngstown Vindicator. (December 19, 1973). Ask Gilligan Cut River Standards. [Source: Clippings file on Mahoning River at the main branch of the Public Library of Youngstown \& Mahoning County]

${ }^{36}$ The Youngstown Vindicator. (January 15, 1974). Agree to Ease River Cleanup. [Source: Clippings file on Mahoning River at the main branch of the Public Library of Youngstown \& Mahoning County]
} 


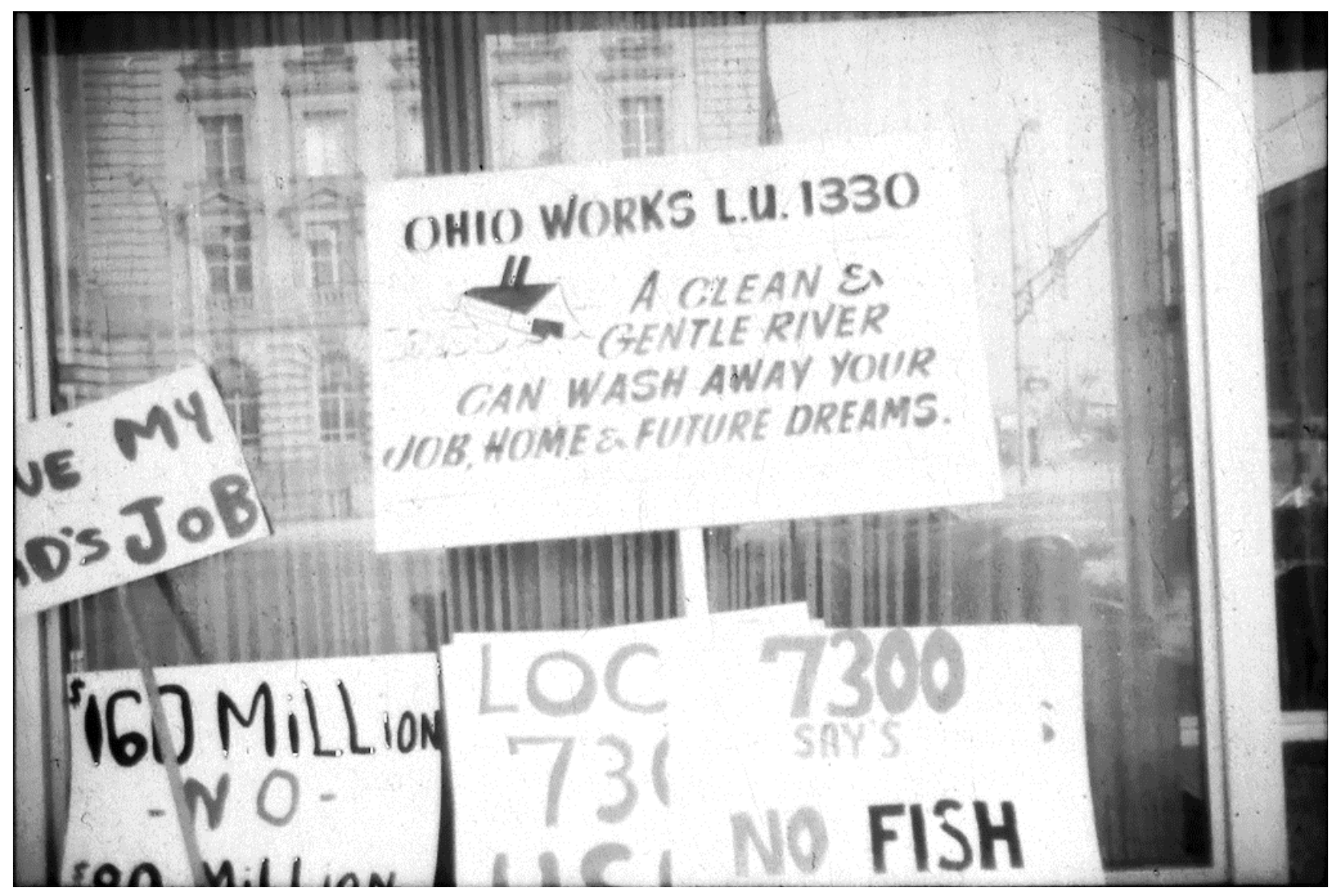

Image 8. Signs at January 1974 EPA hearing at the Voyager Inn in Youngstown, Ohio; photo from Grassroots Magazine archives, taken by Al Garcia, used by permission of Kathryn Wozniak

In $1974 \mathrm{Al}$ Garcia took this photo in downtown Youngstown at a demonstration outside an EPA hearing about the Mahoning River. Hand-lettered signs like the ones on the left and lower edges of the picture were carried by many of the steelworkers who turned out that day to oppose stricter controls on what the steel industry could do to the river.

At the hearing, according to the New York Times, the community expressed fears that cleaning the river would lead to economic ruin, so "[w]hile an endless line of local public officials and other witnesses paraded before the packed meeting room, all of them condemning the proposed requirements, 500 steelworkers marched outside carrying signs that read, 'We want jobs, not fish' and 'Steel, not eel." ${ }^{37}$ But the professionally printed sign at the center of Garcia's photo bears a less strident, almost poetic message: 'A Clean \& Gentle River Can Wash Away Your Job, Home \& Future Dreams.' A small picture of a mill building floating in choppy water balances out this message from the USWA local at the Ohio Works of U.S. Steel.

Viewed more than forty-five years later, this placard gives a sense that the sign-maker understood why people would want a river to be clean and gentle - compare it to Congressman Kirwan's pragmatic declaration that the Mahoning always would be an 'industrial stream.' But however

\footnotetext{
${ }^{37}$ Rattner, Steven. (April 5,1976). Jobs and Not Fish Win in Ohio Steel Town. The New York Times. https://www.nytimes.com/1976/04/05/archives/jobs-and-not-fish-win-in-ohio-steel-town-jobs-not-fish-win-inohio.html
} 
eloquent it might have been, the message printed on this sign also represented a point of view that clearly lacked forethought. Because in the 1970s the Steel Valley was changing in ways that many working people at that demonstration likely would not have expected. And these changes had little to do with the cleanliness of the river. A short description of the events of just four years - from 1973 to 1977 - will illustrate the harsh unpredictability of this pivotal time for steelworkers in the Mahoning Valley.

In 1973, the leadership of the Steelworkers Union entered into the Experimental Negotiating Agreement with the steel industry, which would mean workers could not strike when contracts expired. The 1.4 million rank and file members were not consulted about nor did they get to vote on the ENA. At the Brier Hill Works of Sheet \& Tube, the Rank and File Team won office and began to fight against these concessions. ${ }^{38}$

In 1974 the struggles of African-American workers, including activists at the Brier Hill Works, ${ }^{39}$ yielded results when nine steel companies and the Steelworkers Union signed consent decrees after the federal government filed suit against them, charging discrimination on the 'bases of race, sex and national origin. ${ }^{40}$ (Unfortunately, though some workers of color found new jobs in departments other than those to which they had previously been relegated, by the time real change began to take place, deindustrialization was also underway. ${ }^{41}$ )

In 1976 the above-referenced New York Times article, with the apt title of 'Jobs - Not Fish - Win in Ohio Steel Town' explained to the nation why the EPA had decided to 'allow the Mahoning to remain dirty,' despite the heartfelt testimony of local environmentalists like Professor Lauren Schroeder. ${ }^{42}$ This was said to have been done to protect workers' livelihoods because the steel companies depended on the river, just as the workers depended on their jobs at the mills, and environmental regulations would upset that delicate balance.

And then in September of 1977, the Youngstown Sheet \& Tube Company announced that it would shut down the Campbell Works and lay off the workers there. ${ }^{43}$ Soon after, another Sheet \& Tube plant, as well as operations of U.S. Steel and Republic Steel, followed suit. More than 10,000 jobs were lost in the steel industry and thousands more supporting jobs disappeared. And the industry that had said it would have to eliminate jobs if forced not to pollute the river, closed down not long after it received exemptions. After that, at least for a while, the Mahoning Valley had neither jobs (in the steel industry at least) nor fish.

\footnotetext{
${ }^{38}$ Whittenburg, Alice. (March 1974). Challenging the ENA: Steelworkers Demand the Right to Strike! Grassroots Magazine. Progressive Printers, Youngstown, Ohio.

https://alicewhittenburg.com/grassroots_magazine/grassroots_march_1974.pdf

${ }^{39}$ Whittenburg, Alice. (March 1974). Interview with Jim Davis, 'Discrimination in Steel: Past Practice of Union and Company.' Grassroots Magazine. Progressive Printers, Youngstown, Ohio.

https://alicewhittenburg.com/grassroots_magazine/grassroots_march_1974.pdf

${ }^{40}$ UPI. (August 19, 1975). U.S. Court Upholds Steel Industry Pact to End Job Bias. The New York Times. https://www.nytimes.com/1975/08/19/archives/us-court-upholds-steel-industry-pact-to-end-job-bias.html

${ }^{41}$ Franklin, Stephen. (February 18, 2007). Blacks battled for rights before downsizings. Chicago Tribune. https://www.chicagotribune.com/business/chi-070218-black-steelworkers-story-story.html

42 Whittenburg, Alice. (June 17, 2017). The Mahoning River in 2017. Other Homes and Gardens blog. http://otherhomesandgardens.blogspot.com/2017/06/the-mahoning-river-in-2017.html

${ }^{43}$ Lawson, H. William. (September 17, 2007). Remembering Black Monday. Mahoning Valley History blog. http://mahoninghistory.blogspot.com/2007/09/remembering-black-monday.html
} 


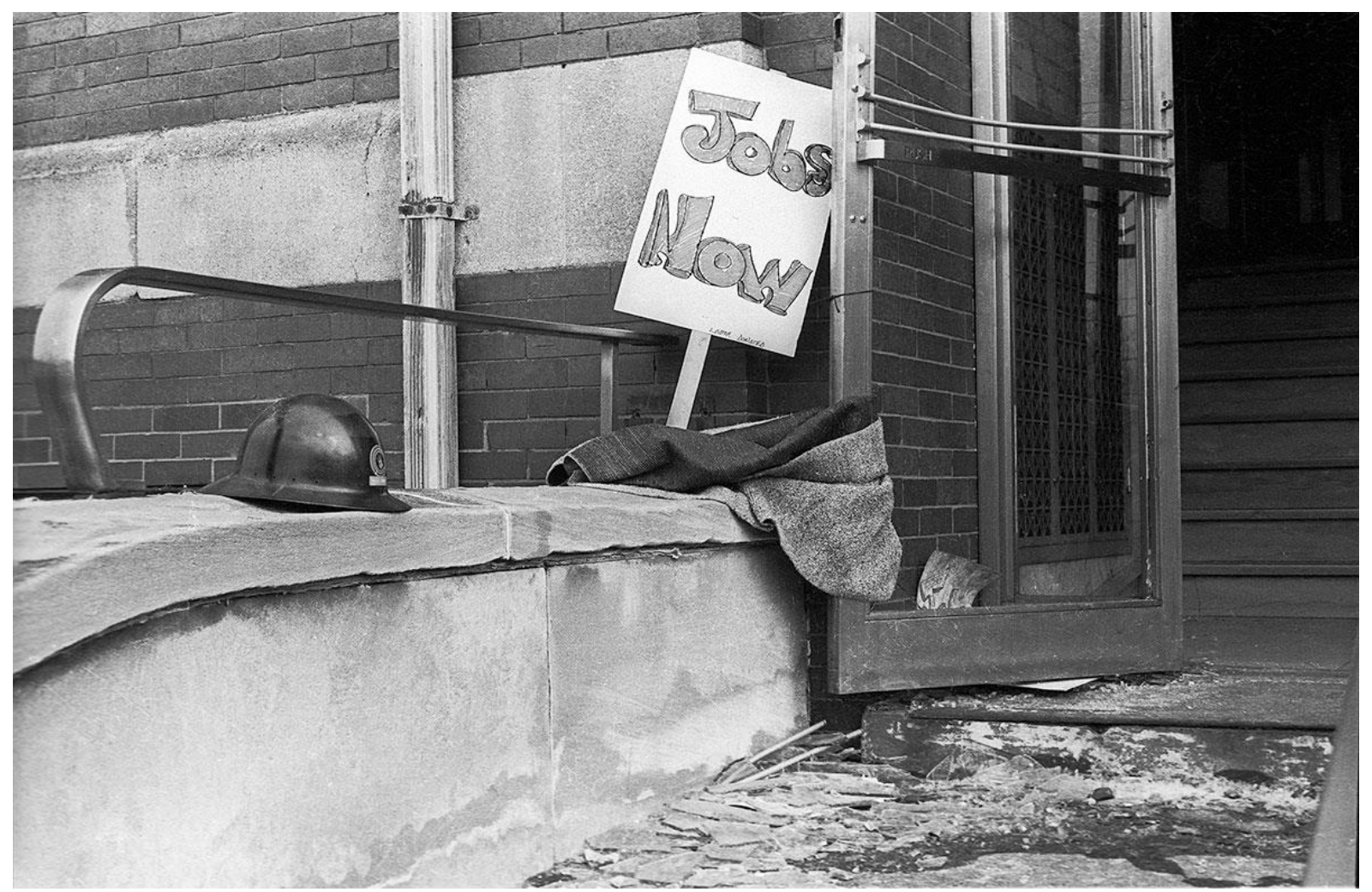

Image 9. Picket sign at a demonstration at McDonald Works of U.S. Steel, 1980. Steve Cagan, photographer. Used by permission.

Steve Cagan's photo is simple but effective: in it a single hand-made picket sign containing two words - 'Jobs Now' - rests on a low cement wall. To the left of the sign there's an abandoned safety helmet. To the right of the sign is an open door through which a stairway can be seen. The doorsill is very worn.

When plant closures were announced, steelworkers in the Mahoning Valley fought against them. Among others, there was a protest at the McDonald Works of U.S. Steel. ${ }^{44}$ Picketing workers carried signs that read 'Keep McDonald Works Open' and 'Keep Jobs in Steel.' During that time steelworkers came together with community activists to form an Ecumenical Coalition that struggled tirelessly to keep the mills from shutting down. Save Our Valley was their demand, but it was not met. ${ }^{45}$

Earlier, in 1977, the EPA released a list of the toxic substances that had been dumped into the Mahoning River each day when the nine steel mills were still operating: they included 400,000 pounds per day of suspended solids, 70,000 pounds per day of oil and grease, 9,000 pounds per

\footnotetext{
${ }^{44}$ Schiller, Zach. (February 26, 2019). Reflections: Staughton Lynd on Youngstown's steel mill closings. Policy Matters Ohio blog. https://www.policymattersohio.org/blog/2019/02/26/reflection-staughton-lynd-on-youngstownssteel-mill-closings

${ }^{45}$ Alperovitz, Gar. (September 25, 2017). Black Monday, '77, When the Mill Shutdown in Youngstown Gave Birth to the Rust Belt. BillMoyers.com. https://billmoyers.com/story/black-monday-77-mill-shutdown-youngstown-gavebirth-rust-belt/
} 
day of ammonia-nitrogen, 800 pounds per day of zinc, 600 pounds per day of phenolics and 500 pounds per day of cyanide. ${ }^{46}$ But when the mills closed down this noxious flood was abated.

From the viewpoint of the river, the valley was saved. From the viewpoint of the steelworkers, the valley was unsaveable.

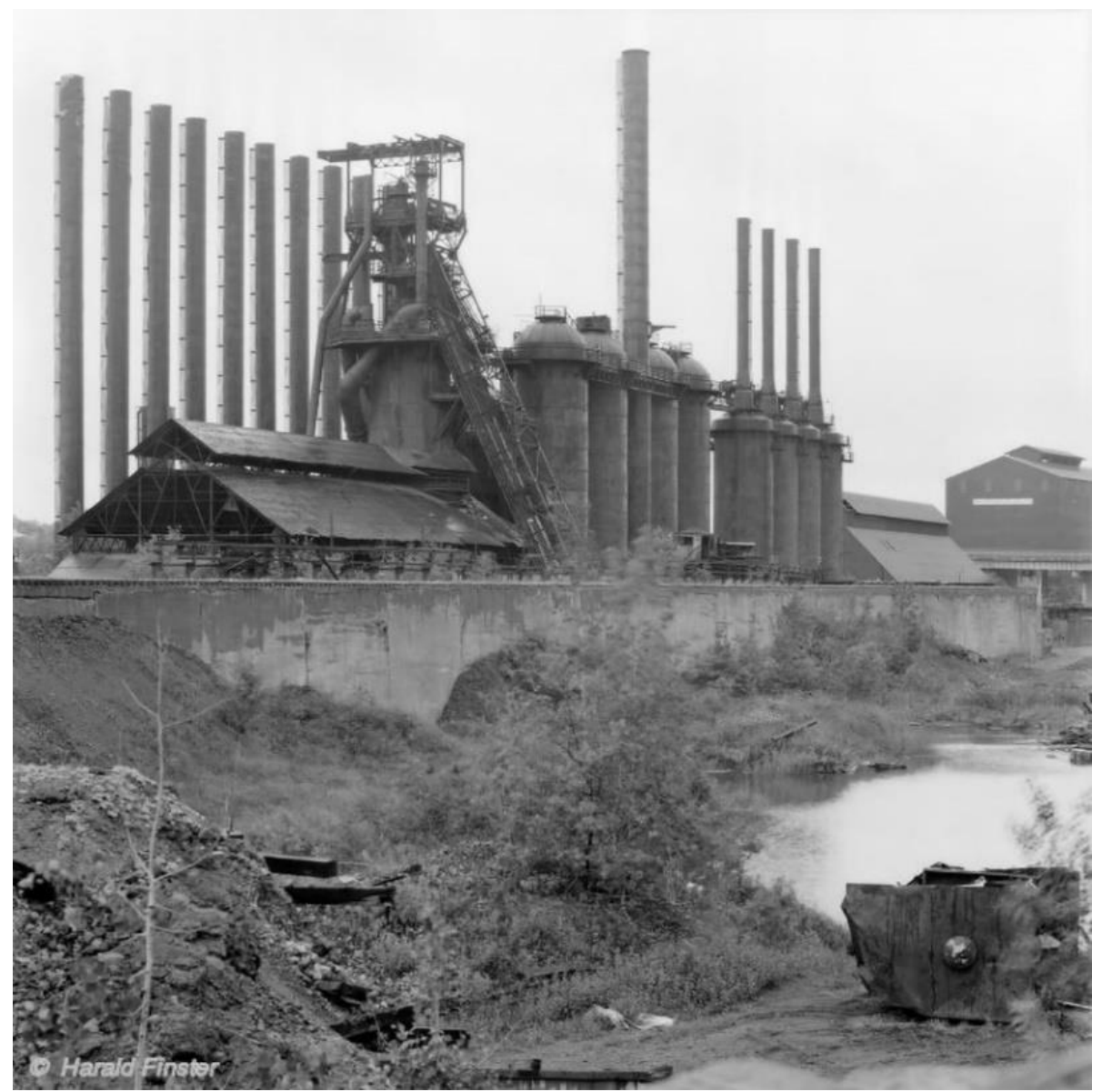

Image 10. Photo of the Jeannette blast furnace at the Brier Hill Works of the Youngstown Sheet and Tube Company, 1992. Photo by Harald Finster, used by permission.

German photographer Harald Finster specializes in industrial and architectural photography, and in 1992 he photographed the Jeanette blast furnace, which at the time was one of the oldest blast furnaces in the United States. On his StahlArt site, Finster expresses an awareness that he has been documenting a world that is in danger of disappearing. ${ }^{47}$

The Jeanette furnace stood, not far from the Mahoning River at the Brier Hill Works of Youngstown Sheet \& Tube, from the time of its creation in 1917-18 until it was destroyed in 1997.

${ }^{46}$ Friends of the Mahoning River. (n.d.) About the River. Friends of the Mahoning River website. Retrieved August 27, 2021. https://friendsofthemahoningriver.org/about-the-river/

${ }^{47}$ Finster, Harald. (May 23, 1992.) Steelworks in Youngstown and Warren (Ohio) and Frequently Asked Questions. StahlArt site. http://www.hfinster.de/StahlArt2/archive-Youngstown-en.html and http://www.hfinster.de/StahlArt2/FAQ-en.html 
It was 90 feet tall, weighed 500 tons, and produced more than 11 million tons of steel. ${ }^{48}$ It is the Jeanette blast furnace Bruce Springsteen sings about in 'Youngstown,' addressing it as 'my sweet Jennie.'

In the 1980s and 90s when the means of steel production in the Mahoning Valley were being dynamited out of existence, fish were returning to the waters of the Mahoning. Deindustrialization was not a healthy process for the people of the Mahoning Valley, and the first fish to come back to the river were not healthy either.

In 1994, EPA workers stunned river fish and examined them; this is what they found: 'Lesions and tumors around their gills. Bacteria-eroded fins and scales. Fish blinded since birth. ${ }^{49}$ All but two of two dozen fish were deformed in some way. But considering that PCBs, cyanide, ammonia, oil, and creosote had been left behind in the sediments of the river, among other toxins, this was probably not a surprise.

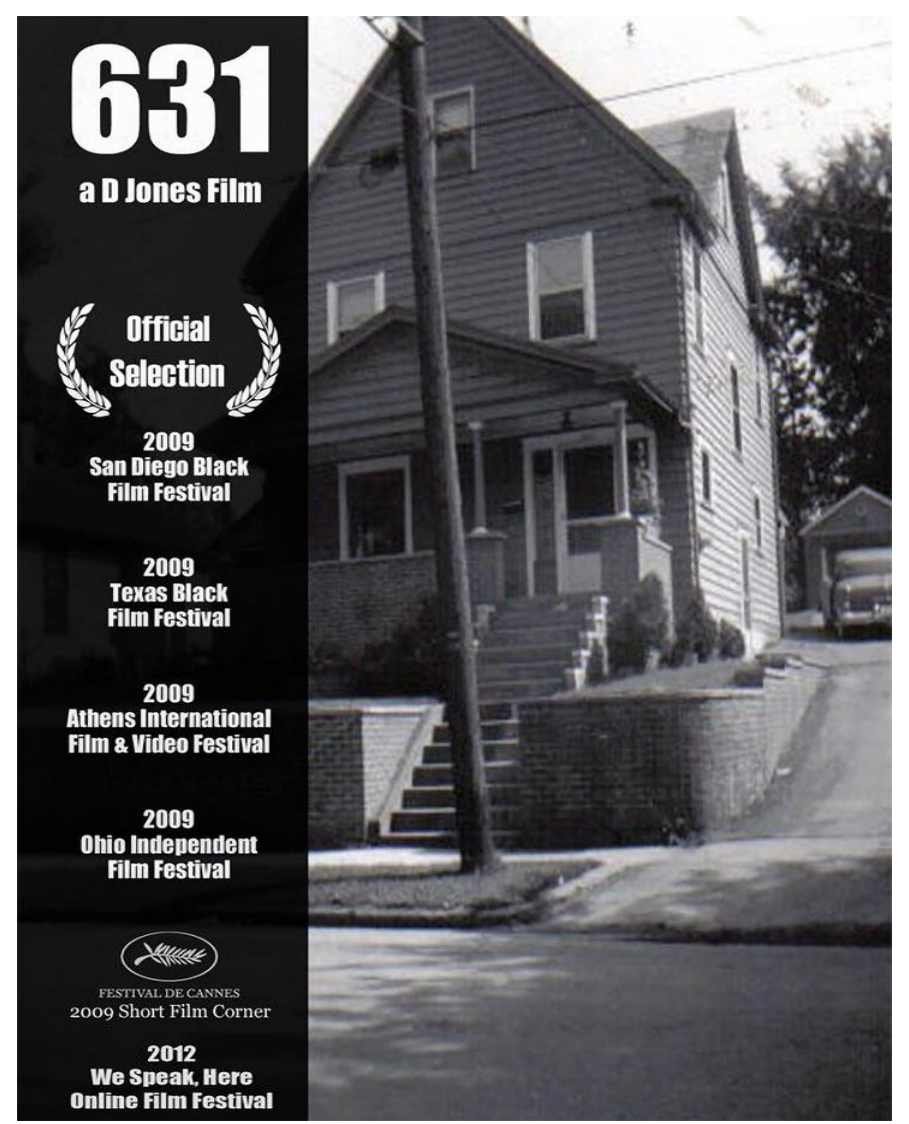

Image 11. Poster for 631, a short film directed and produced by djones, 2008; used by permission.

\footnotetext{
48 the sweet jenny land company (n.d.) the sweet jenny land company website. http:/sweetjennylandcompany.com/jeanette furnace.htm

49 Johnson, Linda J. (February 5, 1995). Sick Fish Tell a Tale of Pollution. See sidebar The Mahoning River Basin, which used data from the Ohio EPA. The Youngstown Vindicator. [Source: Clippings file on Mahoning River at the main branch of the Public Library of Youngstown \& Mahoning County]
} 
This poster for the short film 631 by Derrick Jones (artistically known as djones) features a photo of his family's Youngstown home at 631 Ridge Avenue, the way it looked when his mother was a child. The two-story house has a safe and sheltering appearance, with a sturdy retaining wall that was added, among other improvements, after Jones' grandparents bought the property in the 1950s. Jones grew up there, too, and over many years family gatherings took place in the house, though it also began to need repairs the family was unable to make. Eventually they moved out.

In 631 the importance of the time when Jones' family called the place home is revealed through old photos and the reminiscences of family members. But a poignant sense of loss is expressed in the voiceover at the end of the film: 'You know, I look back on that house, and I think that it's unfair that the only thing that's keeping you from preserving your history or building your legacy in that home is that you just don't have the money to do it. I don't mean the money to get something. I mean the money to keep what's yours. ${ }^{50}$

Twenty years or more before Jones' grandparents bought the house at 631, Youngstown's rate of home ownership was the fifth highest in the country. (Linkon \& Russo, 2002, p. 73) This was largely possible because jobs in the steel industry paid good wages, but in fact many workers, like Jones' grandfather, had professional or managerial jobs. Good jobs paying good wages for working people represented the positive side of what the Mahoning Valley had to offer in the twentieth century.

The fact that Jones' family could buy a house like the one at 631, could make memories there and live a decent life, was one of the reasons immigrants came to Youngstown and African-Americans arrived from the South during the Great Migration. ${ }^{51}$ But as early as the 1920s, Youngstown had become a 'balkanized' city, in which people were divided according to race, national origin, and whether or not they were native born. (Linkon \& Russo, 2002, p. 31) This division was encouraged by the steel companies in the hopes that workers wouldn't band together and organize for better conditions.

At the EPA hearing in 1974, the sign warned that 'A Clean and Gentle River' would wash away your home, and in fact many homes like the one at 631 Ridge have been all but washed from the landscape. But it's always worth remembering that it wasn't the (mostly rescinded) EPA regulations that shut down the steel industry in Youngstown. What closed the mills and created empty lots and abandoned houses was inequality of political and economic power. Steelworkers and their allies couldn't force the steel industry to keep the mills open or to sell them to the workers. ${ }^{52}$ Exacerbated by a racial wealth gap, this inequality of power eventually led to the destruction of neighborhoods. These are problems that no river seems yet to have washed away.

\footnotetext{
${ }^{50} 631$ is available on YouTube: https://www.youtube.com/watch?v=vjWR5oilkno. The filmmaker's bio and a list of his projects can be found on his website at https://adjonesfilm.com/.

${ }^{51}$ For more about The Great Migration, go to University of Washington's America's Great Migrations Project website. (n.d.) The Great Migration (African American).

https://depts.washington.edu/moving1/black_migration.shtml

52 Justia US Law site. (Argued June 18, 1980. Decided July 25, 1980.) Local 1330, United Steel Workers of America, and Frankgeorges, et al., Plaintiffs-appellants. v. United States Steel Corporation, Defendant-appellee, 631 F.2d 1264 (6th Cir. 1980). https://law.justia.com/cases/federal/appellate-courts/F2/631/1264/86708/
} 


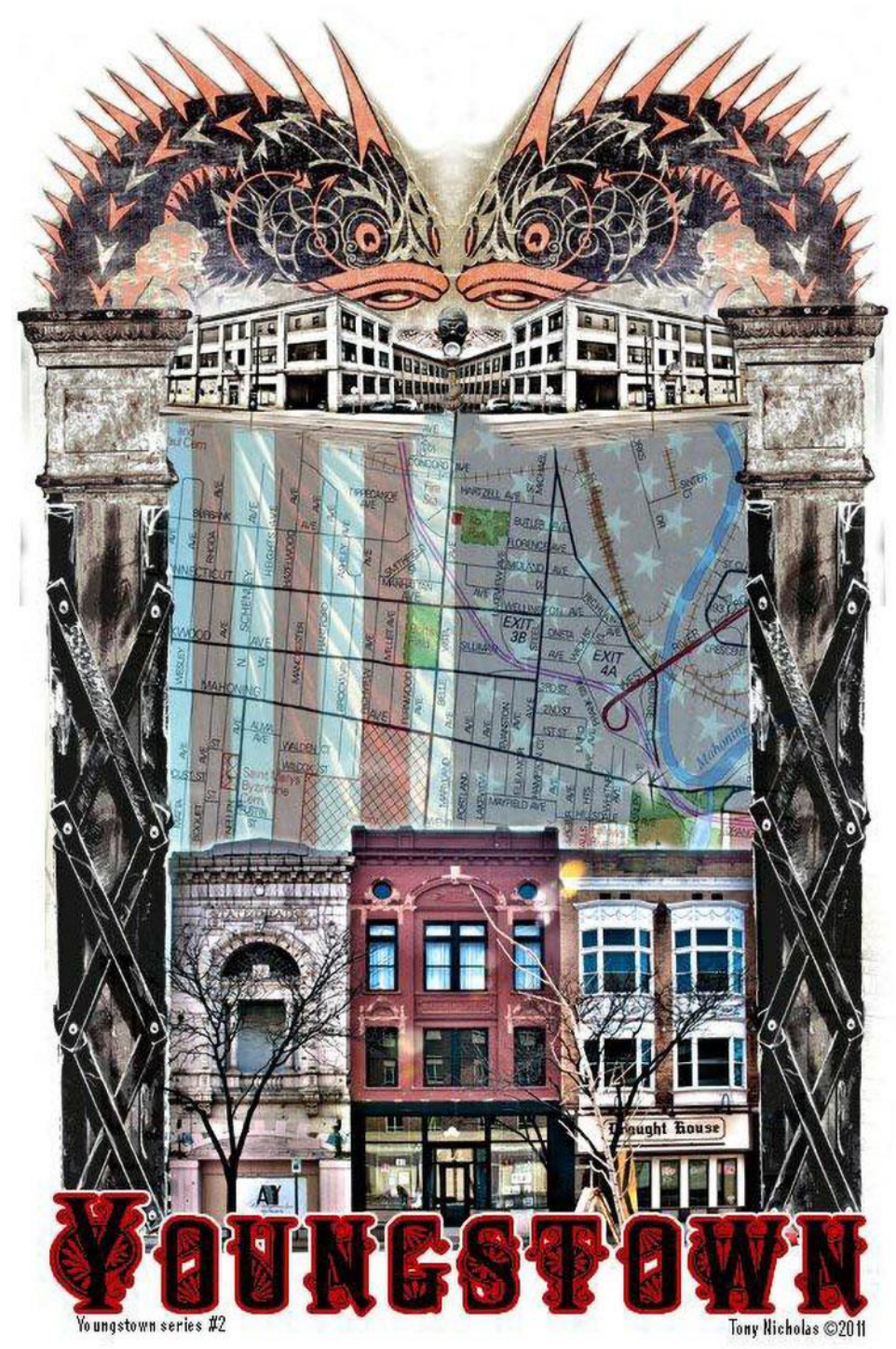

Image 12. Poster from Youngstown series \#2 by Terry Nicholas, 2011. Used by permission.

Available as a poster, this collage by Tony Nicholas contains images of past and present events in the Mahoning Valley and also gives a nod to the notion of Rust Belt chic. ${ }^{53}$ At the top of the collage, mirrored images of the fantastical fish from Barney Carnes' 1931 design make a comeback, along with the companion mermaid. Below them, the Ward Bakery building, which the Ward Bakery Market, Artists, Makers and Collectors call home, is also mirrored; and, like a treasure map hidden in plain sight, a bit of the near west side is shown, which includes a segment of the Mahoning River.

\footnotetext{
${ }^{53}$ Doig, Will. (May 12, 2012). Rust Belt chic: Declining Midwest cities make a comeback. salon.
} https://www.salon.com/2012/05/12/rust_belt_chic_declining_midwest_cities_make_a_comeback/ 
Artists in Youngstown in the 21st century struggle to reinvent themselves, just as workers must do during deindustrialization, and the lore of the Steel Valley has inspired local arts and crafts. The river, too, is prospering once again. That there is now a Youngstown Foundation Amphitheatre for outdoor concerts and a park next to the river is all the more surprising, considering the state of the Mahoning just a few decades ago. ${ }^{54}$ And the rejuvenated river is celebrated each year at Riverfest. As for the fish: According to the 2021 Ohio Sport Fish Consumption Advisory, you can now expect to catch yellow perch, bluegill, common carp, northern pike, rock bass, smallmouth bass, walleye, and channel catfish in the Mahoning River. These fish should be eaten with some degree of caution because of contamination by mercury and PCBs, though compared to what the river could support fifty years ago, this report suggests remarkable biodiversity. ${ }^{55}$

On the other hand, over that same fifty years, the relentless process of deindustrialization has caused the number of good working-class jobs in the Mahoning Valley to continue to decline.

\section{Conclusion}

Despite the improved health of the river, the Mahoning watershed is still affected by the conflict between economy and ecology, as are the people who make their homes in the former Steel Valley. Currently, this conflict centers around hydraulic fracturing, also known as fracking. Fracking and related processes are usually carried out in sparsely populated rural areas and so are less visible than the nine steaming, glaring, smoking mills that once lined the Mahoning River, but concerns about the costs to the environment and benefits to local people are as relevant as they were a hundred years ago. ${ }^{56}$

\footnotetext{
${ }^{54}$ Morrison, Marah. (June 12, 2019). Amphitheater Promises to Spread Green Across Downtown. The Business Journal. https://businessjournaldaily.com/amphitheater-promises-to-spread-green-across-downtown/

${ }^{55}$ Ohio Sport Fish Consumption Advisory. (2021). See the 2021 Ohio Sport Fish Consumption Advisory Table on page 17. https://odh.ohio.gov/wps/wcm/connect/gov/cd619fce-6bcb-4e15-9bf4-

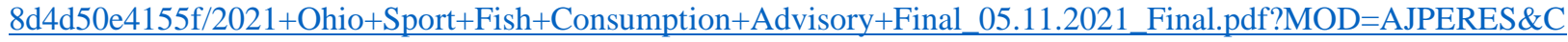
ONVERT TO=url\&CACHEID=ROOTWORKSPACE.Z18_M1HGGIK0N0JO00QO9DDDDM3000-cd619fce6bcb-4e15-9bf4-8d4d50e4155f-nDcENzX

${ }^{56}$ Most often, it's wastewater injection sites that create environmental problems in the Mahoning watershed. Worrisome local consequences have included a 4.0 magnitude earthquake in 2011 and an accident at an injection site which caused oily wastewater to contaminate wells and wetlands in Vienna in 2015. See Gaffney, Austin. (December 3, 2018). Ohio Communities Are Becoming a Dumping Ground for the Fracking Industry. National Resources Defense Council website. https://www.nrdc.org/stories/ohio-communities-are-becoming-dumpingground-fracking-industry. Fracking also produces radioactive waste, some of which is processed in the Mahoning Valley. See (August 8, 2021). Disposal of radioactive fracking waste alarms activists. The Vindicator. https://www.vindy.com/news/local-news/2021/08/disposal-of-radioactive-fracking-waste-alarms-activists/ It's also true that fracking has created several types of jobs in the former Steel Valley. These have included non-union millwright, maintenance, and other positions at French company Vallourec, which opened a plant at the site of the former Brier Hill Works of Sheet \& Tube in 2012. Vallourec manufactures steel pipes for the oil and gas industry. See Kromer, Christopher. (September 30, 2018) Vallourec ramps up hiring in area as gas market improves. Tribune Chronicle website. Retrieved December 11, 2021. https://www.tribtoday.com/news/local-news/2018/09/vallourecramps-up-hiring-in-area-as-gas-market-improves/ In a city that has faced the kind of economic devastation Youngstown has seen in recent years, these jobs have been most welcome. As a result, environmentalists have sometimes been met with negative reactions to their anti-fracking campaigns. See Zremski, Jerry. (May 19, 2014). Youngstown, Ohio, is a city changed by fracking. The Buffalo News. https://buffalonews.com/news/local/youngstown-ohio-is-a-city-changed-by-fracking/article_4c2540b7-49ea-5649$\underline{\text { a13e-4da825642b00.html }}$
} 
In their introduction to Working on Earth: Class and Environmental Justice, Christina Robertson and Jennifer Westerman tell the story of a water well in Pennsylvania that was contaminated by hydraulic fracturing; they then describe the conflict that develops between those who benefit from jobs and other financial incentives of fracking and those who suffer the environmental consequences. This conflict splinters communities as the familiar tensions play out between ecology and economy.

Robertson and Westerman note that working-class people often face a dual injustice as they are exposed to both precarious economic circumstances and environmental harms. This dual injustice is 'reinforced by a social hierarchy where the most affluent groups amass wealth and dominate decision making while assuming less risk of exposure to environmental hazards,' but the choice between jobs and the environment is a false one that harms both working people and the natural world. Instead, Robertson and Westerman call for a working-class ecology that 'challenges industrial policies and practices that divide economic security from environmental health, forcing workers, communities, all sentient beings, and the land to pay dearly for the cost of making a living.' (Robertson \& Westerman, 2015, p. 3)

Arguably, the increasingly mainstream notions of environmental justice and wholistic health have made the need for a working-class ecology clearer. For one thing, the decision made by a stateappointed manager to change the source of drinking water for the city of Flint, Michigan, to the Flint River has raised people's consciousness enormously. ${ }^{57}$ And the justifiable anger of Flint residents over the contamination of their drinking water, as well as the resistance of Native American water protectors at Standing Rock, have brought issues of race and class to the forefront and have fueled a desire for environmental justice. In the Mahoning Valley in the 21st century there has also been a growing consciousness that the link between economy and ecology is human well-being, understood in a wholistic way. ${ }^{58}$ Because working-class people and people of color are more likely to experience environmental harms, they are increasingly seen as necessary coalition partners in the move toward sustainability.

In Working-Class Environmentalism: An Agenda for a Just and Fair Transition to Sustainability, Karen Bell, who has considerable experience as an environmental activist and environmental justice researcher in the UK, expresses her belief that our current situation is at a 'tipping point' in which environmmental issues are 'now increasingly being recognized as fundamental to human

\footnotetext{
${ }^{57}$ It wasn't just coincidence that the corrosive river water leached lead from the pipes of Flint households and created a nightmare for Flint residents, particularly parents who must worry about the long-term effects of lead on their children's health. The Flint River, like the Mahoning, was a 'workhorse' of the industrial era and had been contaminated by human and industrial waste. Treatment of contaminants made the water corrosive and able to leach the lead from Flint households' pipes. See Carmody, Tim. (February 26, 2016). How the Flint River got so toxic. The Verge. https://www.theverge.com/2016/2/26/11117022/flint-michigan-water-crisis-lead-pollution-history The state-appointed manager justified the use of river water as a cost-saving measure, but hundreds of millions of dollars must now be spent to try to address the problems this created - and of course, no amount of money can reverse the devastating effects of lead on young children.

5821 WFMJ. (August 13, 2019). Trumbull NAACP holds community meeting to deter fracking. 21 WFMJ website. https://www.wfmj.com/story/40914458/trumbull-naacp-holds-community-meetingtodeter-fracking
} 
health and wellbeing.' (Bell, 2020, p. 12) She calls attention to the destructive nature of classism and encourages environmentalists to change tactics and recognize that working-class people are important allies. She also points out that the environmental movement should focus on 'companies and governments as the main culprits of unsustainability' and not simply call for changes in personal choice and behaviors. (Bell, 2020, pp. 210-211).

Focusing scrutiny on companies and governments instead of on the behavior of individual citizens can also help us to read the Mahoning River landscape more accurately and to understand the power relations that played out there. After all, it was the steel industry that made the final decision (with the aid of the EPA) not to clean up the river and later made the decision to close down the mills without listening to the demands of the workers and the community. In the future, if environmentalists and working-class people begin to see their common interests and take into consideration such power relations, the conflict between economy and ecology will be easier to resolve. Because people need jobs, it's true, and they need homes, but people also need clean water and a healthy environment in order to live well. And if human beings have a clean and healthy environment, the fish will prosper, too. So in addition to living their own supple, shiny, scaly, slippery lives, fish will function as one of many indicators that real prosperity has arrived at last.

\section{Author Bio}

Alice Whittenburg grew up in the Mahoning Valley when it was the Steel Valley, and her father worked at Republic Steel. As a member of Progressive Printers Collective, which published the short-lived Grassroots Magazine, she attended a 1974 EPA hearing on the Mahoning River in downtown Youngstown. A lifelong interest in the conflict between economy and ecology began at that hearing and inspired this essay.

She now lives in Tucson, Arizona, and co-edits the online magazine The Cafe Irreal. Her essays and fiction have appeared in 3:AM Magazine, The Ekphrastic Review, Atlas \& Alice, and Eclectica Magazine, among others. She is a member of the National Writers Union Tucson Chapter and editor of the Tucson Peace Calendar.

\section{Bibliography}

Bell, K. (2020). Working-Class Environmentalism: An Agenda for a Just and Fair Transition to Sustainability. Palgrave Macmillan.

Linkon, S. L. \& Russo, J. (2002). Steeltown U.S.A.: Work \& Memory in Youngstown. University of Kansas Press.

Robertson, C. \& Westerman, J., Eds. (2015) Working on Earth: Class and Environmental Justice. University of Nevada Press. 